\title{
Network File System Implementation on Computer-Based Exam
}

\author{
Sumarna *, Felix Wuryo Handono, Hafis Nurdin \\ Information Systems Study Program, Sekolah Tinggi Manajemen Informatika dan Komputer Nusa Mandiri, \\ Jl. Kramat Raya No. 18, Jakarta Pusat, Indonesia.
}

Article history:

Submission January 2020

Revised February 2020

Accepted February 2020

${ }^{*}$ Corresponding author:

E-mail:

sumarna@nusamandiri.ac.id

\begin{abstract}
In the world of education, exam is the final stage to evaluate the student ability. The length of the correction process and the expensive cost of printing for manually exams are obstacles that often occurs when administering the exams. Computer-based exams is an effort that is present to solve the problems, by using a computer, then the cost of printing documents and others can be minimized, besides that there is no need for manually correction time, because when students finished the exam, the student's grades can be immediately known. So many advantages are offered by computer-based exams but of course there are still problems that arise. The most common thing is the slow server in processing requests from clients when accessed together, increasing the number of servers using Network File Server is one of the efforts to correct the shortcomings of computer-based exams. Using Network File Server is expected to be able to overcome these problems.
\end{abstract}

Keywords: Network file server, computer based exam, stress test, gatling

\section{Introduction}

The mandate of Preamble of 1945 Constitution of The Republic of Indonesia, states that the state is obliged to develop the nation's intellectual life, shall protect the whole people of Indonesia and the entire homeland of Indonesia, and in order to advance general prosperity, and contribute to the implementation of a world order based on freedom. Based on that, the government seeks to realize it through good and quality education.

One of the efforts in the formation of higher quality education, it is not uncommon for teachers to apply ICT in the teaching and learning process which is packaged in the form of multimedia (audio and video) so it is expected that the teaching and learning process will become more interesting [1]. By utilizing ICT, students can also look for material or competencies that are more relevant, so it is expected that the delivery of material becomes easier to understand [2]. The use of ICT today has also changed the learning process that is generally done in class and at a predetermined time, now it can be done anywhere and anytime without knowing the limitations of space and time [3].
In the learning process, of course there must be an evaluation of each learning process that is carried out. The assessment process is divided into three things, first detecting learning difficulties (assessment as learning), second assessment of the learning process (assessment for learning), and finally is an assessment to measure the achievement of learning outcomes (assessment of learning) [4]. One form of assessment of students during the learning process is by holding an exam, with the aim of obtaining a picture of the achievement of students during the learning process which includes aspects of knowledge, skills and attitudes [5]. However, in the implementation of the exam activities have many problems, ranging from the length of the process of correcting students' answers that can take considerable time and cost to the risk of cheating due to human intervention, so that the test manually cannot describe the ability of students to its true.

Computer-based exams are a solution that can be taken to cover many of the deficiencies caused by manual exams [6]. In a previous study it was also said that the implementation 
of examinations using computers was superior in assessment, report on exam results, security as well as more efficient [7], while also using computer-based exams was expected to be able to minimize the form of cheating caused by human intervention [8] In addition, also because the test is conducted online, every answer from the examinees is directly stored and assessed electronically without any human intervention [9]. The successful implementation of the exam using a computer is not without obstacles, the slow access caused by the number of users accessing the same website and at the same time is an obstacle that needs serious attention [10].

At present, many schools or educational institutions that only use a server to support the computer-based examination process, basically it is not a problem (can be used) but when all students take the exam simultaneously it will be very heavy server burden to handle requests from clients. The slow process of loading questions, the slow process of storing (submitting) answers is something that often occurs when the exam is simultaneously.

Network File Server is a protocol that can be used to access data from computer servers to many clients. By using this NFS, researchers try to make multiple servers with an NFS server as a reference, using this NFS researchers hope that requests from clients are not only handled by a client. server, but the request can be handled by many servers. By using this NFS, researcher also hope that all contents on the main server will be the same as the destination server without removing a single file on the client side.

In this study, researchers tried to implement a Network File System (NFS) to improve website performance, so that there is no longer a slow access to a website when accessed by many users at the same time.

\section{Methods}

In 1980, Sun Microsystems developed a protocol called the Network File System (NFS), originally NFS was used to share files in a diskless work environment [11]. By using NFS, machines contained in a network can access other machine files as if accessing files locally so it can minimize the use of storage on server machines [12]. The server is a computer that has a higher resource than the client's computer that serves to serve, limit or control users and resources in a network. One of so many server types is a Web Server. A web server is a machine with software given that has the function of receiving web page requests via the HTTP or HTTPS protocol from clients or better known as a browser, then sending it back in the form of a web page that is generally from PHP, ASP or HTML content, where the contents contains text, images, audio and video [13].

In this study the authors use the System Development Life Cycle (SDLC) research methodology. This method is a commonly methodology that used to develop, maintain and use information systems, while the stages in this methodology are depicted in the following figure 1:

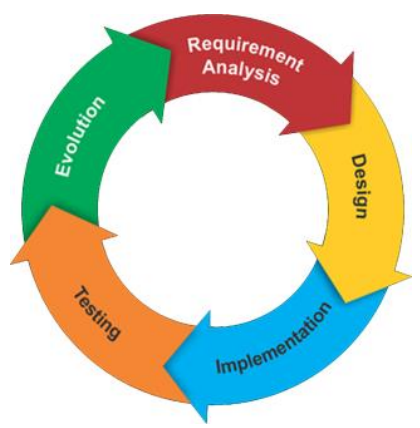

Figure 1. System development life cycle

\section{Analysis}

The authors conducted a literature review from several previous journals related to the problem of examinations using a computer, where in the previous study found problems that when examinations using computers were carried out by many users and at the same time the web machine would be very slow to respond to clients requests, even it can cause down time (death) on the web server, resulting in a test failure.

\section{Design}

At this stage the author makes several designs that will be used to solve the test problems using computers. The first thing the writer does is design the server topology. In this design the author uses four servers. One server is used as an NFS server, where the NFS server functions as a place to put all content that will be loaded by three web server machines using the NFS client. By using this NFS server, all content loaded by the web server will exactly be 
the same content. This is expected to reduce the storage burden on the web server, besides that with this NFS then the programmer does not need to put content on each server that can cause differences between one web server and another.

Figure 2. Computer network topology

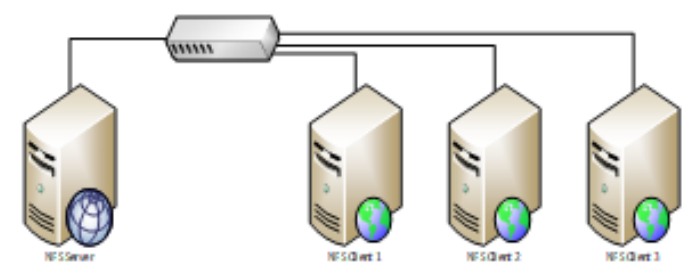

At the next stage, the authors do the system design requirements that will be used by the four servers.

Table 1. System requirement server

\begin{tabular}{clll} 
Server & \multicolumn{2}{c}{$\begin{array}{c}\text { system require- } \\
\text { ment }\end{array}$} & IP Address \\
\hline NFS & CPU & 4 Core \\
Server & RAM & 8 GB & 192.168 .1 .1 \\
& Storage & $40 \mathrm{~GB}$ & \\
NFS Cli- & CPU & 2 Core & \\
ent 1 & RAM & $4 \mathrm{~GB}$ & 192.168 .1 .2 \\
& Storage & $20 \mathrm{~GB}$ & \\
NFS Cli- & CPU & 2 Core & \\
ent 2 & RAM & $4 \mathrm{~GB}$ & 192.168 .1 .3 \\
& Storage & $20 \mathrm{~GB}$ & \\
NFS Cli- & CPU & 2 Core \\
ent 3 & RAM & $4 \mathrm{~GB}$ & 192.168 .1 .4 \\
& Storage & $20 \mathrm{~GB}$ & \\
\hline
\end{tabular}

\section{Implementation}

At this stage, the authors build several servers that will be used to perform NFS testing. These are the stages in developing the server:

a. Operating system installation.

The operating system that authors use on all servers for this research is CentOS, this is because CentOS is a reliable freeware operating system for enterprise scale with a lot of support from the community, besides that centos also has compatibility with Red Hat Enterprise Linux (RHEL) operating system so that the drivers contained in RHEL can be used by centos, and the most important thing in the operating system is their support or support from the developer. Centos has a long support, for once released, it support more than 10 years, so users do not need to worry about bugs or holes in the operating the system for 10 years ahead.

\section{b. NTP Installation.}

NTP is an abbreviation of the Network Time Protocol, while the function of NTP is to use the internet protocol to synchronize time on a computer based on a time reference.

NTP is a very vital thing when building a server, without NTP there will be a significant time difference, this of course will be very influential if it occurs in a banking server for example.

An NTP requires a reference time, so that all servers have the same time. id.pool.ntp.org is one of the references used by many system administrators in Indonesia.

To configure NTP can be done in /etc/ntp.conf, file then add the following lines:

\section{server 0.id.pool.ntp.org \\ restrict 127.0.0.2}

server 0.id.pool.ntp.org: gives a command for the server to sync time by using a reference from the NTP server located on the ntp.org server.

restrict 127.0.0.1: aims to make the NTP on the server computer cannot be accessed by other computers (only for himself) it aims to ease the work of the server from requests from clients who want to synchronize time with the server.

\section{c. NFS Installation.}

NFS or Network File System is a protocol that allows computers to view, write or execute files on other computers through a computer network (remote site).

The first thing to consider to configure NFS is determining the server and client computers, this is due to the configuration files between the server and client are different. On the computer server that needs to be configured is the / etc / exports file and add the following line: 
/var/www/html/sekolah

192.168.1.2(rw,sync, no_root_squash)

/var/www/html/sekolah: Directory to be accessed by other computers.

192.168.1.2: IP address that is allowed to access the computer server.

Rw:Allows client computers to read and write directory contents.

Sync: Synchronize in realtime between the server and clients.

no_root_squash: Used to not give root access to files in that directory for NFS clients

While on the client computer the file that must be configured is, fstab file, where the file is located in / etc / fstab, then fill with:

192.168.1.1:/var/www/html/sekolah

/var/www/html/sekolah nfs defaults 00

192.168.1.1: computer server ip address

/var/www/html/sekolah: the directory on the computer server where to put content from the website

/var/www/html/sekolah: the directory on the computer client where to put content from the website.

\section{d. PHP Installation.}

Hypertext Preprocessor or know as PHP, a server-side programming language that is used to build a dynamic web base application [14], because of its server-side nature, all client requests are executed on the server computer and then the results are sent back again to the client computer, thus the command line available on the computer server will be guaranteed its security, so that the data on the computer server is difficult to retrieve by unauthorized people.

To install php on a computer server can be done with the command

yum install php php-common php-opcache phpmcrypt php-cli php-gd php-curl php-mysql -y

After installation, make sure to run the web server service with this command:

systemctl start httpd then the web server on the server is ready to use.

\section{e. MariaDB Installation.}

MariaDB is a database server that can be used to store and manage data in it [15]. Unlike MySQL which uses SQL (Structured Query Language) as data management, MariaDB uses (relational databases) to manage the data that is in it, by using the relational database MariaDB has a slightly better performance than MySQL.

To install MariaDB into the server machine, the first thing to do is to add the repository manually into the /etc/yum.repos.d/directory, after which we can do the installation by running this command:

\section{yum install MariaDB-server MariaDB-client $-y$}

wait a while until the installation process is complete, after that run the command:

\section{mysql_secure_installation}

This command is used to change the database root password, delete anonymous users, disable remote root logins and activate the database server service.

\section{f. Gatling.}

Gatling is a portable and free stress test application that can simulate access to a destination server with number of users that we can specify. By using Gatling, we will get reports that are easy to read. The report on gatling are in tables and graphs, where information from each graph is different, but gatling generally provides information about the number of users accessing, the number of requests from clients, the time needed to complete requests and what files are accessed by clients. Gatling will be placed on the client. Tables and graphs that will be presented next are the results from the gatling application.

\section{Testing}

For the testing in this research, the authors tested an online exam application ZYA CBT, ZYA CBT is a web base application developed by Achmad Lutfi using PHP and CodeIgniter as 
its programming language, this ZYA CBT application runs with minimum system requirements Apache or Nginx , PHP 5+ and MySQL or MariaDB.

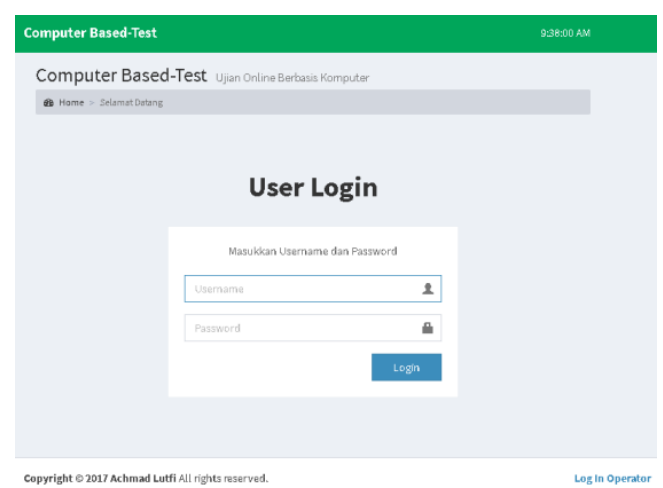

Figure 3. User login page

And to do the stress test, the author uses the Webserver Stress Tool, with this tool the writer simulates number of users accessing the server machine simultaneously in a relatively fast time. Gatling is an open source Webserver Stress Tool application that is commonly used to conduct stress tests on a website, by using this tool we can measure the extent to which the ability of a server machine to handle surges of requests with very large number of users, it can be hundreds or even thousands of requests simultaneously, to be able to use Gatling we must first compile a scenario, where later the scenario will be used by Gatling as a reference for conducting stress tests. Some things that need to be done for the preparation of scenarios are the url or target of the computer server that will be tested (in this case the authors use the page http://ujian.trial.com), the number of concurrent users (users who access at the same time) and the time needed to do the stress test (per user). In this research, the authors conducted several tests, in order to obtain accurate conclusions.

\section{Results and Discussion \\ Testing with one server}

From the test results above, we get information that with 10 concurrent users there are 260 requests, this depends on the number of files that are in the server that is loaded when the page is accessed, the more files that are on the page, then the number of requests will be even greater. Of the total requests given by the clients, the number of requests successfully completed by the server is 260 requests, this indicates that all requests from the client have been successfully completed so that with a concurrent user of 10 users, this computer server will not experience obstacles when completing requests from client.

Table 2. The result of testing with one server

\begin{tabular}{llll}
\hline & \multicolumn{3}{c}{ concurrent } \\
& 10 & 100 & 1000 \\
\hline Total & 260 & 2570 & 10031 \\
Success & 260 & 2482 & 2646 \\
Failed & 0 & 88 & 7385 \\
\% failed & 0 & $3 \%$ & $74 \%$ \\
Min & 19 & 17 & 21 \\
Max & 4619 & 60015 & 60029 \\
Average & 604 & 4257 & 17470 \\
\hline
\end{tabular}

In the table above there is also information about the time needed to complete requests from clients, where for the fastest access time is 19 milliseconds, this speed depends on the size of the file executed by the server, the smaller the size of a file, then the time the server needed to complete it will be even shorter, and vice versa in the table above there is the longest access time of 4619 milliseconds, this indicates that the file is the largest file size in the page of the website.

On the next test, where concurrent users were increased to 100 users, an increase in the number of requests from clients reached 2570 requests, out of the total number of requests there were several requests that failed to be completed by the server with 88 requests or $3 \%$.

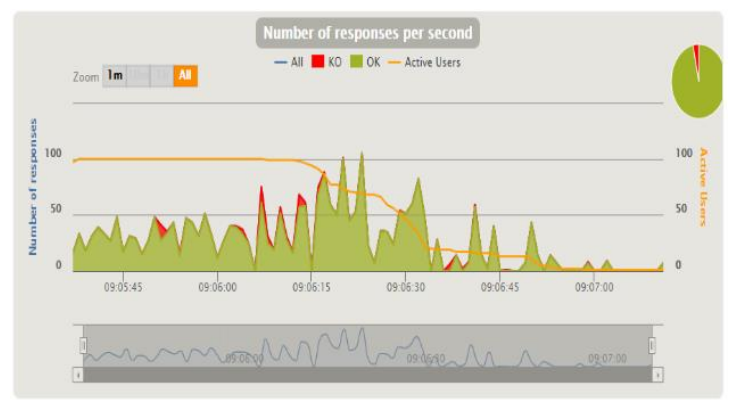

Figure 4. The response result of 100 users 
The failure of the server engine to execute this certainly affects some users who will fail to load the website pages visited, this is seen in the figure above, which indicates an error occurs at different times, so it can be ascertained that there will be a number of users who fail to load the intended website page.

In testing with 100 users, there appears to be a decrease in access time for files with the smallest size of $17 \mathrm{~ms}, 2 \mathrm{~ms}$ slower than testing with 10 users, but for large file access times there is a very large increase, this will very influential when the user access will feel a very long process of loading the website page.

Still using the same server, but the next test is increasing again the number of users to 1000 users, with many of the number of users simultaneously accessing the information in the table above that the server has failed to complete $74 \%$ of the total 10031 requests given by the user, this can be said the server is unable to serving that many users.

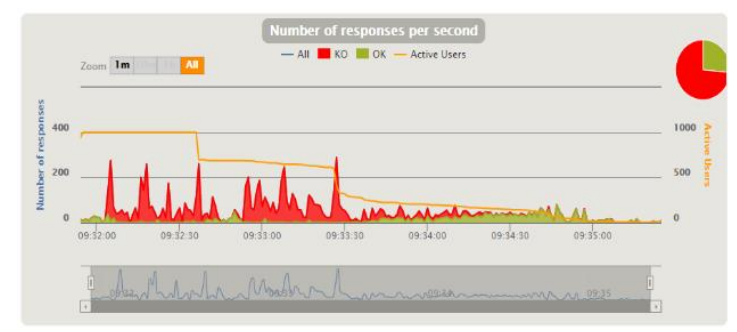

Figure 5. The response result of 1000 users

From the figure above, we also get information that with 1000 users, the server will experience a malfunction so that it will only display an error message window on the server visited and failure to load the website page. we can also get from the table above, where the average time given by the server to display a web page is 17470 milliseconds, this would be very long for a user to use the page fully open.

\section{Testing with two servers}

In testing using three servers, for the number of users as many as 10 users successfully completed perfectly with the fastest average time compared with the previous test, while for the number of users 100 and 1000 still experience failures in completing requests from clients, but the response time is slightly better than the previous test.

Table 3. The result of testing with one servers

\begin{tabular}{llll}
\hline & \multicolumn{3}{c}{ concurrent users } \\
& 10 & 100 & 1000 \\
\hline Total & 260 & 2390 & 9148 \\
Success & 260 & 2265 & 2139 \\
Failed & 0 & 125 & 7009 \\
$\%$ failed & 0 & $5 \%$ & $77 \%$ \\
Min & 20 & 17 & 14 \\
Max & 1388 & 60003 & 60149 \\
Average & 276 & 4611 & 19751 \\
\hline
\end{tabular}

After several tests as described above, here are the overall results that can be compared as in the graph figure 6:

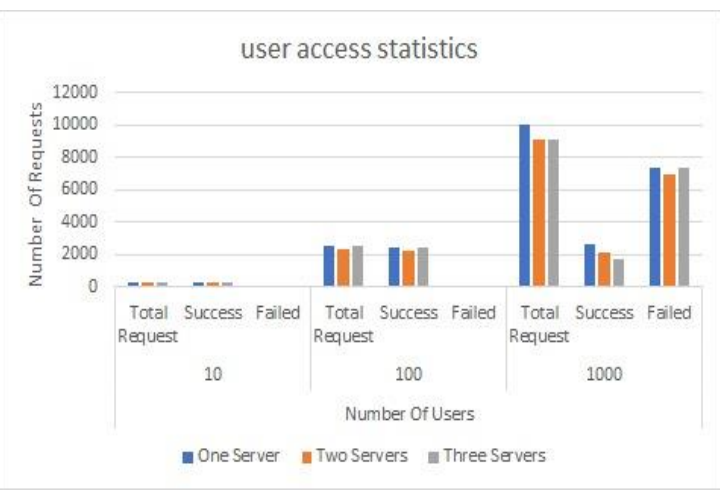

Figure 6. Comparison of overall test results

\section{Conclusion}

Based on the results of the above research, Network file server as an effort to increase the number of servers that are expected to be able to solve the problem of computer-based exams when the user access simultaneously apparently cannot solve these problems. By using the network file server there are still many failed requests from the client side so that the webpage that the client is pointing to is not open so that it can threaten the failure of the test. The network file server is only able to speed up the process of response time from the client so that the time needed by the client to be able to see the entire contents of the website is faster, this is due to requests that come from the client. Not only served by one server but 
many servers. More servers that handle requests from clients will be directly proportional to the response time of the client.

\section{Acknowledgment}

Especially grateful to researchers who have previously conducted research on computerbased exams so that we can take several sources of writing as our reference. We also thank our institution for helping to provide the tools needed for our research testing.

\section{References}

1. Tanrere M, Side S (2012) Pengembangan media chemoedutainment melalui software macromedia flash $\mathrm{mx}$ pada pembelajaran IPA Kimia SMP. J. Pendidik. dan Kebud. 18(2): 156. doi: 10.24832/jpnk.v18i2.77.

2. Waldopo W (2011) Analisis kebutuhan terhadap program multi media interaktif sebagai media pembelajaran. J. Pendidik. dan Kebud. 17(2):244. doi: 10.24832/jpnk.v17i2.21.

3. Nurchaili (2010) Pengaruh media pembelajaran berbasis teknologi informasi dalam proses pembelajaran kimia terhadap peningkatan hasil belajar siswa. J. Pendidik. dan Kebud. 16(6): 648. doi: 10.24832/jpnk.v16i6.493.

4. Pakpahan R (2016) Model ujian nasional berbasis komputer: manfaat dan tantangan. J. Pendidik. dan Kebud. 1(1): 19. doi: 10.24832/jpnk.v1i1.225.

5. Astuti WP, Wibawanto H, Khumaedi M (2015) Pengembangan instrumen penilaian unjuk kerja praktik perawatan kulit wajah berbasis kompetensi di Universitas Negeri Semarang. J. Educ. Res. Eval. 4(2): 8-14.

6. Susilowati S, Hidayat T (2018) Rancang Bangun Sistem Informasi Ujian Online ( Studi Kasus Pada SMAN 58 Jakarta ). J. Tek. Komput. 4(1): 7.
7. Kusaeri A, Hamdani, Suparto, Irmanila E (2018) Komparasi Kredibilitas Penyelenggaraan UNBK dan UNKP Pada Pelajaran Matematika. J. Ilmu Pendidik. 24(1): 10-18.

8. Sapriati A (2009) Ujian Berbasis Komputer ( UBK ): Studi Kasus Penyelenggaraan Ujian. J. Pendidik. Terbuka dan Jarak Jauh l (10): 1-9.

9. Sugiyono TR, Sutarman (2018) Indonesian Journal of Business Intelligence. Indones. J. Bus. Intell. (1) 1: 39-44, 2018.

10. Dosen J, Dakwah F, Uin K, Dosen AF, Dakwah F, Ar-raniry KUIN. Hambatan pelayanan kartu hasil studi (khs) mahasiswa 1: 124-146.

11. Sidik, Putra M (2018) Implementasi Network Attached Storage (NAS) menggunakan synology Disk Station Manager ( DSM 5 . 2) untuk optimalisasi data sharing center. J. Tek. Komput. AMIK BSI IV (2): 39-47. doi: 10.31294/jtk.v4i2.3508.

12. Frederius A, Data M, Yahya W (2019) Implementasi penyimpanan data persisten pada Docker Swarm Menggunakan Network File System ( NFS ). J. Pengemb. Teknol. Inf. dan Ilmu Komput. Univ. Brawijaya. 3(2): 90889096.

13. Sujana AP (2019) Implementasi cluster server pada raspberry Pi dengan menggunakan metode load balancing. Komputika J. Sist. Komput. 8(1): 37-43. doi: 10.34010/komputika.v8i1.1623.

14. Lavarino D (2016) Rancang bangun E - voting berbasis website Di Universitas Negeri Surabaya. J. Manaj. Inform. 6(1): 72-81, 2016

15. Warman I, Ramdaniansyah R (2018) Analisis perbandingan kinerja query database management system (Dbms) antara MySQL 5.7.16 dan MARIADB 10.1. J. Teknoif. 6(1): 32-41. doi: 10.21063/jtif.2018.v6.1.32-41. 